\title{
The effect of betel habits on blood glucose levels in the Karo
}

\section{ethnic community, Karo district [version 1; peer review: 1}

\section{approved with reservations]}

\author{
Yunita Sari Pane (iD)1, Yetty Machrina(iD), Nurfida Khairina Arrasyid³, \\ Mutiara Indah Sari (D) 4 \\ 1Department of Pharmacology and Therapeutics, Faculty of Medicine, Universitas Sumatera Utara, Medan, North Sumatra, 20155,
Indonesia
2Department of Physiology, Faculty of Medicine, Universitas Sumatera Utara, Medan, North Sumatra, 20155, Indonesia
3Department of Parasitology, Faculty of Medicine, Universitas Sumatera Utara, Medan, North Sumatra, 20155, Indonesia
${ }^{4}$ Department of Biochemistry, Faculty of Medicine, Universitas Sumatera Utara, Medan, North Sumatra, 20155, Indonesia
}

V1 First published: 26 Jan 2022, 11:100

https://doi.org/10.12688/f1000research.75763.1

Second version: 18 Aug 2022, 11:100

https://doi.org/10.12688/f1000research.75763.2

Latest published: 18 Oct 2022, 11:100

https://doi.org/10.12688/f1000research.75763.3

\section{Abstract}

Background: Betel is a hereditary tradition from the ancestors of the Batak-Karo tribe, Indonesia. Karo people believe that betel is their unifier. The betel process begins with concocting a mixture of ingredients such as betel leaf, lime, gambier, areca nut, and with/without tobacco addition, then chewed slowly. Our previous study showed that gambier extracts (Uncaria gambier Roxb), can reduce blood glucose levels (BGL) in type 2 diabetes mellitus (T2DM) patients. This study aimed to analyze whether the habit of chewing betel can affect BGL in the Karo ethnic community in the Karo district. Methods: In total, 48 participants from the Karo community were divided into 4 groups (n=12 per group), namely: I. non-T2DM participants without betel habits; II. non-T2DM participants with betel habit; III. T2DM participants without betel habit and IV. T2DM participants with betel habit. The sampling technique was consecutive sampling. Data were collected by interviews and blood sampling (fasted and 2 hours postprandial (2hPP)). The collected data were analyzed by ANOVA then post hoc Bonferroni with a significance level of p-value $<0.05$.

Results: This study showed that fasting BGL had no difference in nonT2DM participants without betel habit (group-I) compared to nonT2DM participants with betel habit (group-II) (84.33 \pm 12.32 vs $81.00 \pm$ 4,84 ), and T2DM participants without betel habit (group-III) compared to T2DM participants with betel habit (group-IV) (196.25 \pm 104.81 vs $150.00 \pm 42.45), p>0.05$. On the other hand, there was a significant difference in BGL 2hPP in group T2DM participants with betel habit 
compared to all groups $(p<0.05)$. T2DM participants without betel habit group had the highest BGL levels compared to other groups. Conclusions: This study concluded that the habit of chewing betel containing gambier is effective in restraining the rate of increase in blood glucose levels. Further research is needed to see the mechanism.

\section{Keywords}

betel, gambir, T2DM, blood glucose levels, Batak-Karo ethnics

Corresponding author: Yunita Sari Pane (yunita@usu.ac.id)

Author roles: Pane YS: Conceptualization, Data Curation, Formal Analysis, Funding Acquisition, Investigation, Methodology, Supervision, Validation, Writing - Original Draft Preparation, Writing - Review \& Editing; Machrina Y: Investigation, Writing - Review \& Editing; Arrasyid NK: Data Curation, Formal Analysis; Sari MI: Methodology, Resources

Competing interests: No competing interests were disclosed.

Grant information: This work was supported by the Indonesian Ministry of Science and Higher Education, number: 66/UN5.2.3.1/PPM/KP-DRPM/2021.

The funders had no role in study design, data collection and analysis, decision to publish, or preparation of the manuscript.

Copyright: $\odot 2022$ Pane YS et al. This is an open access article distributed under the terms of the Creative Commons Attribution License, which permits unrestricted use, distribution, and reproduction in any medium, provided the original work is properly cited.

How to cite this article: Pane YS, Machrina Y, Arrasyid NK and Sari MI. The effect of betel habits on blood glucose levels in the Karo ethnic community, Karo district [version 1; peer review: 1 approved with reservations] F1000Research 2022, 11:100

https://doi.org/10.12688/f1000research.75763.1

First published: 26 Jan 2022, 11:100 https://doi.org/10.12688/f1000research.75763.1 


\section{Introduction}

Betel is a cultural tradition of Indonesian society with one of its compositions being gambier. Gambier (Uncaria gambier $R o x b)$ is mixed with several other ingredients then wrapped in betel leaf which is then chewed slowly. People who chew betel regularly have their own reasons why they have the habit, other than taste. Chewing is a hereditary tradition from ancestors in the Karo tribe. The Karo people believe that betel is a unifying activity for them (Perangin-angin, 2017).

The habit of betel is usually done 3 times a day, namely in the morning, after lunch and at night (Kanapathy, 2014). The habit of betel is mostly seen in women of the Karo tribe, but there are also men who do it, because chewing betel is always done when meeting with relatives, colleagues or in other social settings (Sinuhaji, 2010). According to data derived from interviews, chewing betel provides benefits, namely to enjoy pleasures such as smoking, for leisure, and to eliminate bad breath. Chewing betel has been done for generations and because of the belief that this activity can strengthen teeth (Flora et al., 2012) as well as maintain health.

Chewing betel has been a habit in society for a long time, but nowadays we rarely encounter it, because there has been a shift in values, even though in rural areas there are still many habits that must be participated in because they uphold the traditions of generations (Perangin-angin, 2017). Chewing betel is done in different ways from one country to another and from one region to another in the same country (Gupta \& Ray, 2004). However, the composition of betel is relatively consistent, consisting of betel leaf, betel nut (Areca Catechu), lime (calcium hydroxide) and gambier (Uncaria gambier Roxb) (Lombu, 2014).

The content of catechin polyphenols in gambier is efficacious as an anti-oxidant that may prevent various diseases, such as diabetes mellitus (Umeno et al., 2016). This is evidenced in the research of Pane et al. (2018) which states that gambier extract is efficacious in the treatment of diabetes by increasing levels of superoxide dismutase and lowering blood glucose levels (BGL).

From the description above, the researchers wanted to assess whether the habit of chewing betel can affect BGL in subjects with T2DM compared to participants without T2DM, studied in the Batak-Karo tribe in Karo District.

\section{Methods}

Ethical considerations

This research obtained ethical approval from the Health Research Ethics Committee of the University of North Sumatra (No. 468/KEP/USU/2021). Participants gave written informed consent after receiving an explanation from the researcher regarding the research procedure they would undergo (Pane et al., 2022).

\section{Participants}

The sample size was estimated following data from Kawamori et al. (2014) for BGL fasting and BGL 2hPP, using the following formula:
* Calculation for sample size of BGL fasting

$$
\begin{aligned}
& \sigma^{2}=\frac{(\mathrm{n} 1-1) S 1^{2}+(\mathrm{n} 2-1) S 2^{2}}{(n 1+n 2-2)} \sigma^{2}=\frac{(88-1) 107^{2}+(33-1) 77^{2}}{(88+33-2)} \\
& \sigma^{2}=\frac{996,063+189,728}{119} \\
& \sigma=\sqrt{9,964.630} \\
& \mathrm{n}=\frac{\left.2 \sigma^{2}\left(Z / 1-\frac{\alpha}{2}\right)^{+} Z_{(1-\beta)}\right)^{2}}{(\mu 1-\mu 2)^{2}} \\
& \mathrm{n}=2(99.82)^{2} \frac{(1.64+0.842)^{2}}{\left(-134-(-14)^{2}\right.} \\
& \mathrm{n}=2(9,964.03) \frac{(2,482)^{2}}{(-120)^{2}} \\
& \mathrm{n}=2(9,964.03) \frac{(6.160)}{(14,400)} \\
& \mathrm{n}=2(9,964.03)(0.000428) \\
& \mathbf{n}=\mathbf{8 . 5 3} \\
& \mathbf{n} \approx \mathbf{9} \text { participants. }
\end{aligned}
$$

* Calculation for sample size of BGL 2hPP

$$
\begin{gathered}
\sigma^{2}=\frac{(\mathrm{n} 1-1) S 1^{2}+(\mathrm{n} 2-1) S 2^{2}}{(n 1+n 2-2)} \\
\sigma^{2}=\frac{(88-1) 43.6^{2}+(33-1) 39.8^{2}}{(88+33-2)} \\
\sigma^{2}=\frac{(87) 1,900.96+(32) 1,584.04}{(119)} \\
\sigma^{2}=\frac{165,383.52+50,689.28}{119} \\
\sigma=\sqrt{1,815.74} \\
\sigma=42.61
\end{gathered}
$$

$\mathrm{n}=2 \sigma^{2} \frac{(z \alpha+z \beta)^{2}}{(\mu 1-\mu 2)^{2}}$

$\mathrm{n}=2(42.61)^{2} \frac{(1.64+0.842)^{2}}{\left(-50.2-(-4.2)^{2}\right.}$

$\mathrm{n}=2(1,815.61) \frac{(1.64+0.842)^{2}}{\left(-50.2-(-4.2)^{2}\right.}$

$\mathrm{n}=2(1,815.61) \frac{6.160}{2,116}$

$\mathrm{n}=2(1,815.61)(0.0029)$

$\mathrm{n}=\mathbf{1 0 . 5 3}$ participants

$\mathrm{n} \approx 11$ participants. 
The calculation of the number of samples in the fasting BGL group is minimal 9 participants, while in the 2hPP BGL group minimal 11 participants.

The number of samples used in this study was taken from the largest number which calculated based on sample size formula from the two groups (BGL fasting or BGL 2hPP). The largest number of samples was taken from the BGL $2 \mathrm{hPP}$ group i.e: 11 participants. However, to anticipate the possibility of dropped out, the number of participants is added by $10 \%$ from a total of 11 participants $=12$ people.

So from the 4 groups studied each consisted of 12 participants.

$\sigma^{2}=$ population variance; $\sigma=$ population standard deviation (SD); $n=$ total number of samples each group $\left(n_{1}=88 ; n_{2}=33\right)$; $Z_{\left(1-\frac{\alpha}{2}\right)}=$ value in the standard normal distribution equal to the level of significance $\alpha=1.64 ; \mathrm{Z}_{(1-\beta)}=$ value in the standard normal distribution equal to the desired, $\beta=0.842 ; \mu_{1}=$ mean outcome exposed/treatment group $(-134 \mathrm{mg} / \mathrm{dl})$ for BGL fasting and $(-50.2 \mathrm{mg} / \mathrm{dl})$ for BGL $2 \mathrm{hPP}) ; \mu_{2}=$ mean outcome unexposed/placebo group $(-14 \mathrm{mg} / \mathrm{dl})$ for fasting BGL and $(-4.2 \mathrm{mg} / \mathrm{dl})$ for $2 \mathrm{hPP}$ BGL; $\mathrm{S}_{1}=\mathrm{SD}$ changes from baseline treatment group $(107 \mathrm{mg} / \mathrm{dl})$ for fasting BGL and $(43.6 \mathrm{mg} / \mathrm{dl})$ for $2 \mathrm{hPP} \mathrm{BGL} ; \mathrm{S}_{2}=\mathrm{SD}$ changes from baseline placebo group (77 mg/dl) for fasting BGL and $(39.8 \mathrm{mg} / \mathrm{dl})$ for 2hPP BGL. (see data from Table 2 in Kawamori et al., 2014).

Participants were divided into four groups based on feedback from the questionnaire regarding their betel habits: Group-I. Non T2DM participants without betel habit; II. Non T2DMparticipants with betel habit; III. T2DMparticipants without betel habit and IV. T2DMparticipants with betel habit. Inclusion criteria were participants with 2 generations of the native Karo Batak tribe, aged between 20-70 years. Exclusion criteria were subjects who have a chronic disease (complication), such as liver disease, kidney disease, cardiovascular disease, lung disease, etc, and T2DM participants on insulin therapy.

The sampling technique used was consecutive sampling. The prospective participants were approached to join the study by conducting a survey previously to the research location to see the betel habits of the Karo people. After that, the research team visited the local health service center (Puskesmas Dolat Rayat) to find out about health data and the betel habits of the local community. Then assisted by Puskesmas staff in collecting participants. Then a time was determined at which the research team met directly and gave an explanation of the aims and objectives of the researcher to research the local community. The research team explained the benefits of betel habits for health, especially to reduce blood glucose levels in T2DM patients because of the presence of gambier (Uncaria gambier Roxb) as one of the components in betel which has an antioxidant effect that can reduce $\mathrm{BGL}$.

\section{Data collection}

This research was conducted from July 2021 to October 2021 at the Puskesmas Dolat Rayat Karo District. Data collection of the betel habits of the subjects in this study was done via questionnaire and blood sampling to measure data BGL. These were done on the same day. The questionnaire asked for the following information: name, age, education, occupation, history of illness, history of medicine, family history of illness, betel habit.

Before taking blood, subjects were asked to fast (at home) from $10 .^{00} \mathrm{pm}$ to $08 . .^{00}$ am (around 10 hours) the next day. Blood samples were taken at $08 .^{00}$ am straight after fasting (fasting BGL). Following this, the subjects consumed 100 grams of white bread, and 2 hours later the blood was taken again (BGL 2h postprandial [PP]).

Blood was drawn from the participant's fingertip and BGL level checked using a glucometer (Family Dr® Blood Glucose Monitoring System, AGM-513S, All Medicus Co., Ltd.). The following steps were taken:

1. Wash the participant's hands, use an alcohol swab. Make sure the finger are dry before testing.

2. Insert a test strip into the glucometer.

3. Set up the lancing device, unscrew the cap on the lancing device. Insert the lancet into the lancing device, then twist off the cap on the lancet, recap the lancing device by screwing the top back on next set the depth of the lancing device

4. Slide the cocking handle back

5. Hold the finger and place the lancing device firmly on the side of the finger and push the button

6. Squeeze from the palm of the hand down to the tip of the finger to obtain a drop of blood

7. Place the blood sample on the test strip

8. The glucometer does the assessment and gives the result

\section{Statistical analysis}

The data collected were analyzed using SPSS version 20 by ANOVA and post hoc Bonferroni test with a significance value of $\mathrm{p}<0.05$.

\section{Results}

The participants in this study were the Karo tribe from 2 generations of pure Karo natives. Of 49 potential participants, 48 were eligible to take part (Pane et al., 2022). The characteristics of the distribution of participants based on betel habits, as follows:

Table 1 shows there were 12 participants in each of the 4 groups studied. It was found that 14 participants $(29,17 \%)$ in the betel habit groups had a frequency of betel $>10$ times a day, and the duration of betel habit as more than 10 years compared to less than 10 years was equal (12 participants, $25 \%$ in each group). Most participants (16 people; 33,33 \%) reported benefits of betel to maintain health, especially mind relaxation (mood) and extra benefit for healthy and strong teeth, while others had no special reason for using betel, only to follow their customs ( 8 people; 16,67\%). In the T2DM group, there were 21 participants $(43,75 \%)$ who had chewed betel suffering from diabetes 
Table 1. Distribution of respondents based on the betel chewing habit of the Batak-Karo tribe in Karo District. T2DM=type 2 diabetes mellitus.

\begin{tabular}{|c|c|c|}
\hline & $n$ & Percentage (\%) \\
\hline $\begin{array}{l}\text { Study group } \\
\text { - Non T2DM without betel habit } \\
\text { - Non T2DM with betel habit } \\
\text { - T2DM without betel habit } \\
\text { - T2DM with betel habit }\end{array}$ & $\begin{array}{l}12 \\
12 \\
12 \\
12\end{array}$ & $\begin{array}{l}25 \\
25 \\
25 \\
25\end{array}$ \\
\hline $\begin{array}{l}\text { Gender } \\
\text { - Men } \\
\text { - Women }\end{array}$ & $\begin{array}{l}11 \\
37\end{array}$ & $\begin{array}{l}22.92 \\
77.08\end{array}$ \\
\hline $\begin{array}{l}\text { Age } \\
\begin{array}{l}-\quad 20-30 \\
-\quad 31-40 \\
-\quad 41-50 \\
-51-60 \\
-\quad 61-70\end{array}\end{array}$ & $\begin{array}{c}5 \\
9 \\
9 \\
16 \\
9\end{array}$ & $\begin{array}{l}10.42 \\
18.75 \\
18.75 \\
33.33 \\
18.75\end{array}$ \\
\hline $\begin{array}{l}\text { Body mass index } \\
\text { - Under weight } \\
\text { - Normal weight } \\
\text { - Overweight } \\
\text { - Obese Class-I } \\
\text { - Obese Class-II } \\
\text { - Obese Class-III }\end{array}$ & $\begin{array}{c}1 \\
19 \\
17 \\
6 \\
4 \\
1\end{array}$ & $\begin{array}{c}2.08 \\
39.58 \\
35.42 \\
12.5 \\
8.33 \\
2.08\end{array}$ \\
\hline $\begin{array}{l}\text { Duration of T2DM } \\
->10 \text { years } \\
-\quad<10 \text { years } \\
-\quad \text { Never }\end{array}$ & $\begin{array}{c}3 \\
21 \\
24\end{array}$ & $\begin{array}{c}6.25 \\
43.75 \\
50\end{array}$ \\
\hline $\begin{array}{l}\text { Betel Frequency } \\
\text { - Often }>10 x \text { in daily } \\
\text { - Sometimes/rarely }<10 x \text { in daily } \\
\text { - Never }\end{array}$ & $\begin{array}{l}14 \\
10 \\
24\end{array}$ & $\begin{array}{c}29.17 \\
20.83 \\
50\end{array}$ \\
\hline $\begin{array}{l}\text { Duration of Betel habit } \\
-\quad>10 \text { years } \\
-\quad<10 \text { years } \\
-\quad \text { Never }\end{array}$ & $\begin{array}{l}12 \\
12 \\
24\end{array}$ & $\begin{array}{l}25 \\
25 \\
50\end{array}$ \\
\hline $\begin{array}{l}\text { Aims of betel } \\
\text { - Calms the mind (mood), make the } \\
\text { teeth be healthy and strong } \\
\text { - Only as habit/tradition } \\
\text { - Never }\end{array}$ & $\begin{array}{c}8 \\
24\end{array}$ & $\begin{array}{c}33.33 \\
16.67 \\
50\end{array}$ \\
\hline $\begin{array}{l}\text { Effects of betel (felt comfort, change } \\
\text { coloring teeth, fresh condition feeling, } \\
\text { irritation in mouth, red lips, etc) } \\
\text { - Yes } \\
\text { - No }\end{array}$ & $\begin{array}{l}24 \\
24\end{array}$ & $\begin{array}{l}50 \\
50\end{array}$ \\
\hline
\end{tabular}

\begin{tabular}{|l|c|c|}
\hline & $\mathbf{n}$ & Percentage (\%) \\
\hline Education & & \\
\hline - No School & 2 & 4.17 \\
\hline - Elementary school & 5 & 10.42 \\
\hline - Junior high school & 5 & 10.42 \\
\hline - Senior high school & 26 & 54.17 \\
\hline - Academic & 4 & 8.33 \\
\hline - Undergraduate & 5 & 10.42 \\
- Magister & 1 & 2.08 \\
\hline Occupation & & \\
\hline - Retired/pension & & \\
- Housewife/no work & 1 & 2.08 \\
\hline - Entrepreneur/sales & 15 & 31.25 \\
- Civil employee & 9 & 18.75 \\
\hline - Private employee & 5 & 10.42 \\
\hline - Farmer & 4 & 8.33 \\
\hline
\end{tabular}

for $<10$ years. The participants included 11 men $(22,92 \%)$ and 37 women $(77,08 \%)$. The most populous age group was 51-60 years (19 participants; 33,3\%) and least was 20-30 years (5 participants; 10,42 \%). The most populous BMI category was the normal-weight group (19 participants; 39,58\%). The BMI group below normal weight included 1 person $(2,08 \%)$. The other participants were above normal weight. BMI classification was based on WHO (2021). Most participants had at least Senior High School level education (26 participant; 54,17\%). Some worked as farmers (14 participants; 29,17\%) but the largest number of participants were housewives (15 participants; $31,25 \%)$.

Table 2 shows the BGL of participants based on with/without betel habits in the non- T2DM and T2DM groups.

This study showed that for fasting BGL there was no significant difference between group I vs -II $(84.33 \pm 12.32$ vs 81.00 $\pm 4.84 ; \mathrm{p}=1,000)$, and group-III compared to group-IV (196.25 \pm 104.81 vs $150.00 \pm 42.45 ; \mathrm{p}=0.317)$. There was no significant difference in BGL between the comparison of the betel and the no-betel groups. However, there was a difference between group -I compared to group III $(84.33 \pm 12.32$ vs $196.25 \pm$ 104.81; $\mathrm{p}=0.000)$ and groups I-IV $(84.33 \pm 12.32$ vs $150.00 \pm$ 42.45; $\mathrm{p}=0.042$ ) which shows the significant difference of BGL. Similarly, group-II was compared with group-III $(81.00 \pm 4.84$ vs $196.25 \pm 104.81 ; \mathrm{p}=0.000)$ and group-II was compared to group-IV $(81.00 \pm 4.84$ vs $150.00 \pm 42.45 ; \mathrm{p}=0.029)$ showing statistically significant differences in fasting BGL (see Table 2).

In BGL 2hPP, there was no significantly difference between group-I vs -II $(112.25 \pm 22.62$ vs $108.33 \pm 18.99 ; \mathrm{p}=1,000)$. On the other hand, comparisons of all other groups showed significant differences in BGL, such as: group-I compared group-III $(112.25 \pm 22.62$ vs $314.92 \pm 128.97 \mathrm{mg} / \mathrm{dl})(\mathrm{p}=0.000)$; 
group-I compared group-IV $(112.25 \pm 22.62$ vs $229.25 \pm 58.26$ $\mathrm{mg} / \mathrm{dl}) \quad(\mathrm{p}=0.001) ;$ group-II compared group-III $(108.33 \pm$ 18.99 vs $314.92 \pm 128.97 \mathrm{mg} / \mathrm{dl})(\mathrm{p}=0.000)$, group-II compared group-IV $(108.33 \pm 18.99$ vs $229.25 \pm 58.26 \mathrm{mg} / \mathrm{dl})(\mathrm{p}=0.001)$ and group-III compared group-IV (314.92 \pm 128.97 vs $229.25 \pm 58.26$ $\mathrm{mg} / \mathrm{dl})(\mathrm{p}=0.035)($ Table 2).

Table 2 shows the differences in a gap of BGL in each group and the magnitude of the increase in BGL fasting compared to BGL 2 hours postprandial. The difference in the increase in BGL groups I and II was almost the same, namely 26.92 and $27.33 \mathrm{mg} / \mathrm{dl}$, not exceeding normal glucose levels in both fasting and 2 hours postprandial conditions with/without habit betel. But the highest BGL difference was found in group III-T2DM without betel habits, which was $118.67 \mathrm{mg} / \mathrm{dl}$. Meanwhile, in the T2DM with betel habits (group-IV), the gap between BGL fasting and BGL2hPP was only $79.25 \mathrm{mg} / \mathrm{dl}$. This indicates that the betel habit can restrain the increase in BGL as seen in groups IV compared to group III.

\section{Discussion}

The frequency of betel habit among participants in this study varied. In two groups (-II and -IV), 14 participants from a total of 24 participants in those groups had betel habits $>10$ times a day $(29.17 \%)$. The results of this study are the same as Kanapathy's study (2014), in which 14 samples of a total of 25 had betel habit frequency $>10$ times a day.

In the present study, the highest percentage of participants suffering from Diabetes Mellitus (DM) for less than 10 years was 21 participants $(43.75 \%)$, in contrast to the findings of Budiharto (2018), who found that 15 out of 25 people $(60 \%)$ who had suffered from DM long-term and had a 1 betel habit for more than 10 years. The main purpose of betel habits found in this study (16 participants, 33.33\%) was to get a sense of comfort and dental health. This is supported by Budiharto's research (2018) which reported that out of a total of 25 participants (13 participants, 52\%) the habit of chewing betel had the same effect. In contrast, the results of other researchers showed that as many as $68 \%$ of participants experienced porous teeth and poor oral hygiene due to betel. This could be because the subjects studied did not maintain oral hygiene, or lacked the knowledge about how to maintain oral health by chewing betel (Andriyani, 2005).
The habit of chewing betel is often found in rural areas in Karo Regency. Chewing betel is a hereditary culture that has become a tradition of the Karo tribe to this day. This is supported by research conducted by Perangin-Angin (2017) which states that the Karo people have a tradition that involves betel activities in a series of Karo customs. However, unlike the Karo people in the countryside, the Karo people in urban areas are rarely found to have the habit of chewing betel. This may be due to hygiene factors (when they chew betel, their teeth change to turn blackish red, and also differences in busy urban lifestyles whereas Karo people who live in urban areas do not have much time to gather while chewing betel together).

Betel habit generally uses a mixture of betel leaf, lime (calcium hydroxide), gambier, areca nut, sometimes with or without the addition of tobacco. Gambier is known to prevent various diseases because besides being efficacious as an anti-inflammatory, it is also a strong anti-oxidant. Pane et al. (2018) reported that gambier can reduce blood glucose levels in T2DM patients by increasing levels of superoxide dismutase resulting in a decrease in malondialdehyde formation and an increase in pancreatic function in producing insulin. In the present study, we suggested that the habit of chewing betel can control BGL because of the efficacy of gambier which is one of the components in betel. It was proved in the results that there were differences in BGL in each group with an increase in the rate of fasting BGL and 2 hours postprandial BGL which can be compared as follows: The T2DM group with betel habits (-IV) had a lower difference in the increase in BGL (79.25) $\mathrm{mg} / \mathrm{dl}$ compared to the T2DM group without betel (-III; 118.67) $\mathrm{mg} / \mathrm{dl}$. In the group that has the habit of consuming betel, glucose levels are lower than the group that does not have the habit of consuming betel. We assumed that gambier consumed as part of their betel habit has the ability to bind oxidants produced by metabolism when blood glucose levels are high, thus affecting the function of the pancreas to produce insulin. This therefore causes a suppressed rate of increase in BGL in participants who are suffering from T2DM with betel habit. However, in the non-T2DM group (-I and -II), both groups with or without betel habits had BGL within normal limits. Gambier (Uncaria gambier Roxb) which is rich in catechins plays a role in the normalization of BGL (Sugiyama, 2005). Most importantly, the anti-oxidant catechin molecules in gambier are safe, which were identified as the main bioactive

Table 2. Blood glucose levels (BGL) after fasting and $\mathbf{2}$ hours postprandial (2hPP). T2DM=type 2 diabetes mellitus.

\begin{tabular}{|l|l|r|r|}
\hline Groups & BGLfasting (mg/dl) & BGL $\mathbf{~ h P P ~}(\mathbf{m g} / \mathbf{d l})$ & Gap of BGL (mg/dl) \\
\hline I. Non-T2DM participants without betel habit & $84.33 \pm 12.32$ & $111.25 \pm 22.62$ & 26.92 \\
\hline II. Non-T2DM participants with betel habit & $81.00 \pm 4.84$ & $108.33 \pm 18.99$ & 27.33 \\
\hline III.T2DM participants without betel habit & $196.25 \pm 104.81$ & $314.92 \pm 128.97$ & 118.67 \\
\hline IV.T2DM participants with betel habit & $150.00 \pm 42.45$ & $229.25 \pm 58.26$ & 79.25 \\
\hline
\end{tabular}


compounds in gambier (Anggraini et al., 2011). Catechins can improve diabetes and its complications by modifying oxidative stress (p<0.05) (Pane et al., 2018; Samarghandian et al., 2017).

Comparing the fasting BGL between groups, there was no statistically significant difference between group non T2DM participants without betel habit (-I) and non T2DM participants with betel habit (-II); and also group T2DM participants without betel habit(-III) compared T2DM participants with betel habit (-IV), $p>0.05$. However, there were statistically significant differences between BGL in group-III and group-I and group-III and group-II; group-IV and group-I; group-IV and group-III, $\mathrm{p}<0.05$.

While the comparison of BGL 2 hours postprandial showed a significant difference between each group $(p<0.05)$, except for the comparison of BGL group I and group II there was no significant difference $(\mathrm{p}=1,000)$.

The difference between fasting BGL and 2hPP was found in the non-betel (-III) T2DM group which had the highest BGL compared to the other groups. Similarly, the comparison of the largest differences in the increase in BGL rates was shown in group III. We assume that in group III there is no gambier to suppress BGL levels, in contrast to the group that has the habit of chewing betel, it seems that BGL levels are restrained. The comparison of fasting BGL and $2 \mathrm{hPP}$ in group with betel habit (-II and -IV) was lower than the group without betel habit (-I and -III). Another interesting thing in this study showed that there was no suppression of BLG below the normal threshold in BGL fasting and BGL $2 \mathrm{hPP}$ condition in the group of non T2DMparticipants with betel habit (group-II). The limit of normal BGL = $72-108 \mathrm{mh} / \mathrm{dL}$ (Mathew \& Tadi, 2021).

The limitations of this study were that it is not easy to collect samples that have betel habits such as groups-II and -IV, due to the small number of samples in the population. In addition, in a pandemic situation, people do not want to be at in the Public Health Center for long, especially for T2DM with/without betel habit groups. However, every step in this study was carried out under strict health protocol procedures.

\section{Conclusion}

This study concluded that betel habits can restrain the increase in BGL as seen in a comparison of T2DM participants with betel habit (group-IV) compared to T2DM participants without betel habit (group-III). But this wasn't the case when comparing participants without T2DM.

\section{Data availability}

Underlying data

Figshare: The Effect of Betel Habits on Blood Glucose Levels in Karo ethnic community in Karo District. https://doi.org/10.6084/ m9.figshare.17871911 (Pane et al., 2022).

This project contains the following underlying data:

- 2021-data.xlsx (raw data in Indonesian)

- Output.xlsx (statistical analysis)

\section{Extended data}

Figshare: The Effect of Betel Habits on Blood Glucose Levels in Karo ethnic community in Karo District. https://doi.org/10.6084/ m9.figshare.17871911 (Pane et al., 2022).

This project contains the following extended data:

- Informed Consent.pdf

- Certificate Clinical Trial Yunita Sari Pane.pdf

- ethical clearance.pdf

- QUESIONER PENELITIAN-20122021.docx (questionnaire in Indonesian)

- Lampiran-sign.docx (information sheet in Indonesian)

Data are available under the terms of the Creative Commons Zero "No rights reserved" data waiver (CC0 1.0 Public domain dedication).

\section{Acknowledgments}

The authors would like to thank Laboratorium Terpadu, Faculty of Medicine, Universitas Sumatera Utara, for providing the place and facilities to conduct the research.
Andriyani: Efek Menyirih terhadap Gigi dan Jaringan Lunak Mulut. Skripsi: Fakultas Kedokteran Gigi Universitas Sumatera Utara, 2005. Reference Source

Anggraini T, Tai A, Yoshino T, et al.: Antioxidative activity and catechin content of four kinds of Uncaria gambir extracts from West Sumatra, Indonesia. Faculty of Agricultural Technology, Andalas University. West Sumatera. African Journal of Biochemistry Research. 2011; 5(1): 33-38. Reference Source

Budiharto MD: Status Kesehatan Perempuan dengan Kebiasaan Menyirih di Kabanjahe Kabupaten Karo. Skrpsi: Fakultas Keperawatan Universitas Sumatera Utara, 2018

Reference Source
Flora S, Christopher T, Mahmudur R: Betel Quid Chewing and its Risk Factors in Bangladeshi Adult. WHO South East-Asian Journal of Public Health. 2012; 1(2): in Banglade. 181.

162-181.
Reference Source

Gupta P, Ray C: Epidemiology of Betel quid usage. Ann Acad Med Singap. 2004; 33(4 Suppl): 31-6. PubMed Abstract

Kanapathy AP: Hubungan Kebiasaan Menyirih dengan Kanker Mulut pada penduduk Komunitas India di lingkungan Klang, Selangor, Malaysia. Skripsi: Fakultas Kedokteran Gigi Universitas Sumatera Utara, 2014. Reference Source

Kawamori R, Kaku K, Hanafusa T, et al.: Effect of combination therapy with 
repaglinide and metformin hydrochloride on glycemic control in Japanese patients with type 2 diabetes mellitus. J Diabetes Investig. 2014; 5(1): 72-79. PubMed Abstract | Publisher Full Text | Free Full Text

Lombu ES: Kebiasaan Menyirih dan Kesehatan Rongga Mulut Lansia di Desa Hilibadalu Kabupaten Nias. Skripsi: Fakultas Kperawatan Universitas Sumatera Utara, 2014

Reference Source

Mathew TK, Tadi P: Blood Glucose Monitoring. In: StatPearls. Treasure Island (FL): StatPearls Publishing; 2021; [Updated 2021 Aug 11].

Reference Source

Pane YS, Ganie RA, Lindarto D, et al.: The effect of gambier extract on the levels of malondialdehyde, superoxide dismutase, and blood glucose type 2 diabetes mellitus patients. Asian Journal of Pharmaceutical and Clinical Research. 2018; 11(10): 121-124.

Publisher Full Text

Pane YS, Machrina Y, Arrasyid NK, et al:: The Effect of Betel Habits on Blood Glucose Levels in Karo ethnic community in Karo District. figshare. Dataset, 2022.

http://www.doi.org/10.6084/m9.figshare.17871911.v1
Perangin-angin SA: Tokoh Adat Dari Marga Perangin-angin. 2017.

Samarghandian S, Azimi-Nezhad M, Farkhondeh T: Catechin treatment ameliorates diabetes and its complications in streptozotocin-induced diabetic rats. Dose Response. 2017; 15(1): 1559325817691158.

PubMed Abstract | Publisher Full Text | Free Full Text

Sinuhaji LN: Perilaku menyirih dan dampaknya terhadap kesehatan yang dirasakan wanita karo di Desa Sempajaya Kecamatan Berastag Kabupaten Karo. Skripsi: Fakultas Kesehatan Masyarakat Universitas Sumatera Utara, 2010.

Reference Source

Sugiyama S: [Pharmacological action of gambir]. Yakushigaku Zasshi. 2005; 40(1): 29-33.

PubMed Abstract

Umeno A, Horie M, Murotomi K, et al.: Antioxidative and antidiabetic effects of natural polyphenols and isoflavones. Molecules. 2016; 21(6): pii:E708. PubMed Abstract | Publisher Full Text | Free Full Text

WHO: Body mass index (BMI). 2021.

Reference Source 


\section{Open Peer Review}

\section{Current Peer Review Status: ?}

\section{Version 1}

Reviewer Report 12 April 2022

https://doi.org/10.5256/f1000research.79681.r121181

(C) 2022 Mustofa M. This is an open access peer review report distributed under the terms of the Creative Commons Attribution License, which permits unrestricted use, distribution, and reproduction in any medium, provided the original work is properly cited.

\section{Mustofa Mustofa}

Department of Pharmacology and Therapy, Faculty of Medicine, Public Health and Nursing (FKKMK), Universitas Gadjah Mada, Yogyakarta, Indonesia

1. The manuscript needs extensive revision for language and grammar. Some editing is required.

2. The inclusion criteria used are not presented specifically.

3. The methods sections normally presented in narration not in instruction.

4. The statistical analysis especially between group III and IV needs to be checked again:

The main objective of the study was to evaluate the effect of betel habits on BGL. Therefore, analysis and discussion should be focused by comparing the results of groups III and IV. The sample size is too small in this study and the standard deviation (SD) is too wide, especially groups III and IV. Normally, in this case, a nonparametric statistic is recommended. In this study, the Anova was applied. Therefore, I recommend using nonparametric statistics with data presented in median +/- range.

5. The conclusion needs revision:

- It was too early to conclude that betel habits can restrain the increase of BGL. The authors did not compare the fasting BGL between group III and group IV. The conclusion just based on the BGL $2 \mathrm{~h}$ PP. Moreover, the conclusion should be revised based on the new statistical Other: analysis results.

The quality of the manuscript should be improved. For example, it is needed to present the calculation of the sample size in this manuscript. The English also should be improved.

Is the work clearly and accurately presented and does it cite the current literature? Partly

Is the study design appropriate and is the work technically sound? Partly 
Are sufficient details of methods and analysis provided to allow replication by others? Yes

If applicable, is the statistical analysis and its interpretation appropriate?

Partly

Are all the source data underlying the results available to ensure full reproducibility? Partly

Are the conclusions drawn adequately supported by the results?

Partly

Competing Interests: No competing interests were disclosed.

Reviewer Expertise: Pharmacology and Ethnopharmacology.

I confirm that I have read this submission and believe that I have an appropriate level of expertise to confirm that it is of an acceptable scientific standard, however I have significant reservations, as outlined above.

Author Response 02 Aug 2022

Yunita Sari Pane, Universitas Sumatera Utara, Medan, Indonesia

Thank you for reviewing and suggesting some constructive amendments to the article.

Answering the question number:

1. We've revised the article for language, grammar, and editing.

2. Inclusion and exclusion criteria have been presented (see page 4).

3. The method section has been presented in narration (see page 4).

4. Statistical analysis of the articles has been adjusted and the discussion has focused more on groups 3 and 4 as suggested.

5. The conclusion of the article has also been fixed

The conclusion of the article has been revised based on improved statistical analysis The conclusion of the sample size calculations has been presented since the inception of the publication

Thank you for your suggestion, we had been trying to improve our ability in scientific language.

Competing Interests: No competing interests were disclosed. 
The benefits of publishing with F1000Research:

- Your article is published within days, with no editorial bias

- You can publish traditional articles, null/negative results, case reports, data notes and more

- The peer review process is transparent and collaborative

- Your article is indexed in PubMed after passing peer review

- Dedicated customer support at every stage

For pre-submission enquiries, contact research@f1000.com 